\title{
Theological War Theories
}

\author{
Andreas Holzem
}

This paper gives an overview of how war theories in Christianity changed during the different periods of western Christianity from the late antiquity to modern times. The basic thesis is that, in contrast to the relationship between war and cult in ancient religions of the old Orient, Greece, and Rome, Christian war theories had not only one, but two functions to fulfill. On the one hand, the Christian religion had to cope with the inheritance of their traditional role models: priests and prophets had to support military force and to secure the victory by divine aid. Bellum iustum in this sense was the cult that pleased the Goddesses/God and ensured their/his backing. On the other hand, bellum iustum in early Christian theology, and ever since, was a problem of peace, restriction of power, and ethically-based self control. After the conversion of Constantine to Christianity, Christian emperors, kings, and princes were inclined to emphasize the first target of Christian religion, while the theologians still had to interpret the moral restrictions on warfare devised by St Augustine, St Thomas Aquinas, Francisco de Vitoria, and the philosophers of the Early modern international law. These competing expectations concerning the relationship of Christianity and warfare led to many ambiguities, all too often precluding a substantial contribution of Christian religion to a more peaceful world.

Christianity in Late antiquity, Medieval, Early modern and Modern times, St Augustin, St Thomas Aquinas, Old Testament, Sermon on the Mount, Constantine, bellum iustum, ethics of peace, crusades, war against heresy, confessionalism, juridification, and nationalization of war

Andreas Holzem is a full Professor at the Catholic Theology Department of the Eberhard-Karls-University Tübingen. He holds a chair in Church History and has recently been a fellow/visiting scholar in Jerusalem, London, and Cambridge. Recent Publications on the topic: Das "Opfer für das Vaterland" - Passionsblut im modernen Krieg, in: Renate Dürr / Annette Gerok-Reiter / Andreas Holzem / Steffen Patzold (eds.), Religiöses Wissen im vormodernen Europa: Schöpfung - Mutterschaft - Passion, Paderborn et al. 2018 [in print]. Christianity in Europe: The 17th Century, in: Jens Holger Schjørring / Norman Hjelm (ed.), The Global History of Christianity, Vol. 1: European and Global Christianity, 1500-1789, Leiden - Boston 2017, 235-319. Krieg und Christentum. Religiöse Gewalttheorien in der Kriegserfahrung des Westens (Krieg in der Geschichte, Vol. 50), Paderborn et al. 2009. 
Andreas Holzem

\section{War Cult and Peace Ethic: The Ambivalent Relationship between Christianity and War}

Nowadays, at the beginning of the $21^{\text {st }}$ Century, the horizon to discuss the problem of religion and war has completely changed. ${ }^{1}$ The end of the cold war, 9/11, the fear of Islamist terror in Europe's great cities, and the ideological inhumanity of the IS-regime in Iraq and Syria raked the anxiety conjoined to the notion of a 'clash of civilisations'. From the 1970s till 1989, the peace movements in Europe and America requested the contribution of religion, especially Christianity, to overcome the conflict of NATO and the Warsaw Pact, claiming nuclear disarmament and remonstrating military stockpile. Since then, the idea of religion in this function being a source of violent fundamentalism has gained increasing approval. Many adherents to western culture receive the impression that monotheism in itself - be it Christian, Muslim or Jewish - is densely connected to the legitimation of war and terror. Therefore, the history of religious wars in Christianity up to George Bush's "war on terror" is read and interpreted as a variant but corresponding version of modern Islamist radicalization.

But war theories circulating in the Christian tradition and in Christianity today are in no way limited to predominantly religiously motivated military conflicts that are identified with the concepts "religious war" or even "holy war." Instead, these theories are concerned in general with Christian religion in all forms and types of war, ${ }^{2}$ as it has informed the West's long and violent military history. The predominantly legitimizing function of Christianity in war is agreed upon by historically interested contemporaries: Ministers and pastors bless the weapons and declare the war goals of attackers or defenders as right and good. Furthermore, they express God's partisanship textually and ritually and promote the continuation of this or that outbreak of the next war as political practice with military means.

However, a religious-historical comparison with pre-Christian and nonChristian religions reveals the narrowness of such common preconceptions, because Christianity had to carry ambivalence into its confrontations with the reality of war. Both in the cultures of the ancient Orient and in Greek-Roman realms of power, the cult of religious war remained intimately connected with political

1 This contribution is only a short, nearly irresponsibly simplifying summary, based on: Holzem, Andreas (ed.): Krieg und Christentum. Religiöse Gewalttheorien in der Kriegserfahrung des Westens (Krieg in der Geschichte, Vol. 50), Paderborn et al. 2009. Annotations are reduced to direct quotations and references. For deeper insights in sources, literature, special debates etc. refer to the manifold contributions to this book.

2 Cf. Beyrau, Dietrich / Hochgeschwender, Michael / Langewiesche, Dieter (eds.): Formen des Krieges: Von der Antike bis zur Gegenwart (Krieg in der Geschichte, Bd. 37), Paderborn et al. 2007. 
authority and military control. ${ }^{3}$ Due to Christianity having aligned itself with the narrative of the people of Israel and the early Judaic tradition in the Hebrew bible, and as this history of Israel cannot be isolated from, but must rather be considered in relation to the history of the people and empire building in the ancient Orient, the specifically Christian aspect has to be clarified in comparison to preceding and neighboring cultures.

\section{Bible and Antiquity}

In the early Oriental and ancient environments in which Christianity arose, no other religions - except Judaism and ancient philosophy ${ }^{4}$ - had sophisticated perspectives on war. There was no priesthood that might represent an independent point of view in any of these cultures (Babylon, Assur, Egypt et al.). Temples were built by royal decree, and temple cults served the wellbeing of the king and his military success. Priests and attendants of the cults declared the king chosen by God and maintained close company with royalty through careful ritual sacrifice and dream interpretation. These cults did not provide spiritual guidance, ethic counseling or sermons; in general, they had no independent prophets. These were appointees of the king, such as the priests of sacrifice, seers, and dream interpreters. They all viewed the king as an executive of God's will or as equal to the gods, and supported him as such. They predicted victory and the downfall of the enemy. They carried cultic images into battle. They celebrated success and archived the cover-ups of losses. ${ }^{5}$ Cult priests saw no missionary intention in these wars. The gods of other kings were considered to exist, though viewed as obviously less powerful. So they were integrated into their own polytheist pantheon under their own chief god. Therefore, there were no 'holy wars' intending to annihilate inferior rituals. Wars were fought over resources: for expansion of lordship, for servile subjects and tribute, for looting weapons and slaves, wood, oil, wine, or for

3 Holzem, Andreas: "Geistliche im Krieg und die Normen des Kriegsverstehens: Ein religionsgeschichtliches Modell zu Ritual, Ethik und Trost zwischen militärischer Kulttradition und christlicher Friedenspflicht", in: Brendle, Franz / Schindling, Anton (eds.): Geistliche im Krieg, Münster 2009, 41-85.

4 Cf. Groß, Walter, "Keine 'Heiligen Kriege' in Israel. Zur Rolle JHWH's in Kriegsdarstellungen der Bücher Jos bis 2Kön”, in: Holzem, Andreas (ed.): Krieg und Christentum: Religiöse Gewalttheorien in der Kriegserfahrung des Westens (Krieg in der Geschichte, Vol. 50), Paderborn et al. 2009, 107-127. Erler, Michael, "Ursachenanalyse von Krieg und Frieden bei Platon und in der hellenistischen Philosophie", in: Holzem, Andreas (ed.): Krieg und Christentum: Religiöse Gewalttheorien in der Kriegserfahrung des Westens (Krieg in der Geschichte, Vol. 50), Paderborn et al. 2009, 169-179.

5 Stietencron, Heinrich von: “Töten im Krieg: Grundlagen und Entwicklungen”, in: Ders. (ed.): Töten im Krieg, Freiburg et al. 1995, 17-53; 34-41. 
passage to an ocean. This explains the general difference in the tendency of Israel's war tales: The flight from Egypt and the periods of settlement and the Judges support an evaluation of the JHWH cult as having a militant, violenceaffirming, and violence-prone stance - in line with the adjacent cultures, but with one substantial difference: the idea of the impurity of all other religions as a step on Israel's long way to monotheism. These texts give a central role to divine action in war: JHWH may bring the enemy within Israel's reach and thus bring about victory through his wondrous intervention. In exchange, however, he demands the complete annihilation of the enemy, not only of the warriors, but of all people, animals and plunder to avoid contact with their contaminant ways of worship (cf. 1 Sam 15; Dtn 20,1-20).

Thereafter, Israel underwent essential religious-historical development: In the Hebrew bible as early as the late Kingdom period, a prophecy arose that was critical of king and war, reaching a climax with Amos and Hosea. The exilic-postexilic (dtn-dtr) treatment of historical material as a deuteronomistic (dtr) interpretation attempted to explain the fall of Israel and the Babylonian exile. Therefore, the Hebrew bible drew on texts that were very critical of royalty, texts that did not suppress narratives of war losses. Instead the bible has a tone that is jealous of God's concern for keeping the covenant between JHWH and his chosen people (Ex 19,3-6; Ex 24). Unlike the narratives of the early Oriental tradition, the downfall was not provoked by God's powerlessness, but by the people's - and particularly the ruler's - consistent violation of the covenant minutes (cf. Hos 1114, Jes 9,7-20; 43,27-28). Many of the reports of Israel's conquer of and settling in Canaan, including the elimination of the local population (Num 21,3; Dtn 2,34; Dtn 3,6; Dtn 7,2; Jos 2,10; Jos 6,17-21; Jos 10,1; Jos 10,28-43; Jos 11,1-23), are nowadays interpreted as a retrospective construction by this deuteronomistic school insisting on strict monotheism. The Old Testament thus attempts to explain violent narratives of extreme military loss as God's punishment for the defiance of religious commandments. The cult priests linked to the kings of Israel and the first Jerusalem temple were history themselves, when this school of theologians began to construe the religious interpretation of Israel's war history.

Christianity's relation to war was ambiguous from the start. It was initially a religion far from the pillars of the Roman state. Jesus himself was denounced by the Roman authorities for blasphemy and instigating uproar; and the missionaries and founders of Christian communities were executed for repudiating Rome's religious traditions. The commandment to love thy neighbor (Mt 5,38-48 par), an absolute basic concept of the earliest records of Jesus-tradition ${ }^{6}$, conflicted with any aggressive interpretation of the relationship to God (cf. Lev 5). The Corpus

6 Luz, Ulrich: "Feindesliebe und Gewaltverzicht: Zur Struktur und Problematik neutestamentlicher Friedensideen", in: Holzem, Andreas (ed.): Krieg und Christentum: Religiöse Gewalttheorien in der Kriegserfahrung des Westens (Krieg in der Geschichte, Vol. 50), Paderborn et al. 2009, 137-149; 137. 
Paulinum aligned itself with the ancient Christian reality as subject to a pagan authority, but refused to participate in its polytheistic cults (Rom 13). The apocalypse predicted massive battles of transcendent powers and the extermination of God's enemies in the End of Days brought about by God (Rev 18/ 20), but these visions were written down not to justify force but to comfort and strengthen helplessly marginalized Christian congregations. ${ }^{7}$ The interpretation of Jesus' renunciation of violence all the way to the cross posed a challenge: Originally, this was a subversive sign against the brutality of rulers. Only centuries later, Christ's suffering was to be seen as opening a special way of succession: Believers taking part in a war were invited to imagine this threat to their life as a sacrifice equal to Jesus'.

Therefore, the early Christians relation to war was double-edged: Firstly, Christian theology in late antiquity took as its central theme not an interpretation of war, but an ethic of peace. Christianity had to be interpreted as applicable to issues of political and military responsibility. Lactantius, Ambrosius, and particularly Augustine did not rule out war completely, but laid out the first rational criteria for its necessity ${ }^{8}$ : war must serve to overcome inaequitas (inequity) and neglect of iustitia (justice) and lex aeterna (eternal law). Thus in actuality, they developed the distinction between ius ad bellum (right to war) and ius in bello (law in war) as well as characteristics of their implementation through ratio (reason) and sapientia (wisdom). Augustine saw passion dominate reason in war; in the Christian interpretation, this was a consequence of man's fall into sin, and of the destruction this incidence left in creation and in humankind's mind. Following pre-Christian philosophy, Augustine contended that the desire to rule (libido dominandi) and the desire to harm others (libido ulciscendi) were weaknesses in the inner unity of the human being. Because a truly Christian order of society ruled by iustitia, caritas and clementia - was assessed as impossible after the fall into sin, state penal powers had to keep judicial order. The "righteous war" was limited to an outpouring of state efforts to establish order, and Augustine did not dispute that most wars of the Roman Empire would thus be considered unjust. At the same time, Augustine argued that the Donatists of North Africa, whose suppression he claimed, should be persecuted not because of their differing beliefs, but because of their tendency towards violence against the community and against the true religion. To oblige them to attend the services of the true church (compelle intrare, cf. Lk 14,23) would, he assumed, reconvert them to the righteous doctrine and peaceful behavior. The "doctrine of peace" that can be read

7 Nicklas, Tobias: "Der Krieg und die Apokalypse: Gedanken zu Offb 19,11-21", in: Holzem, Andreas (ed.): Krieg und Christentum: Religiöse Gewalttheorien in der Kriegserfahrung des Westens (Krieg in der Geschichte, Vol. 50), Paderborn et al. 2009, $150-165 ; 150$.

8 Cf. Weissenberg, Timo J.: Die Friedenslehre des Augustinus: Theologische Grundlagen und ethische Entfaltung, Stuttgart 2005. 
from Augustine's texts saw no role for priests in battle, because war was close to incompatible with divinity. The principle pacem pace non bello (peace through peace and not through war) is the true maxim of Augustine's ethics of peace. ${ }^{9}$ This meant that an intervention in war by clerics was essentially unthinkable.

During the Middle Ages, however, the perspective of reading Augustine had shifted: In their eyes, the church father's interpretation of the Roman emperor's targets shed light on their own self-understanding of being a Christian warrior like Constantine. This emphasis on war instead of peace was intensified by the Old Testament's role model of being a king under God's eyes: The biblical texts were largely interpreted as historically true reports about virtuous rulers. The strong beliefs of military leaders and kings held sway alongside a belief in the assistance of JHWH in victory. Thus Augustine had laid the parameters for later justifications of wars against "idolaters" and "heretics". Declaring the emperor and the European kings as pious rulers in the service of God, violence became explainable as the will of God particularly against the Catharists and Muslims. Augustine's few, restrictive concessions to the option of "just" war were later expanded to the basis of a systematic war ethic. This remained valid in moral theological handbooks into the $20^{\text {th }}$ century. The questions were therefore: How does war fit into Christian life, how can it be reconciled with the will of God, how can Christian societies come to terms with the manifold ideas of God's actions in history and the human sufferings in their aftermath, and what clerical aid - by either motivation or consolation - is acceptable in the effort to construe a meaning of death as well as survival? But it was seldom asked how holding Christian beliefs should limit war. This is the first side: the bible, ancient Christian theology and war, including the tendencies of its further developments.

On the other hand, despite this ambivalence in their holy scriptures and in the ethics of war, during the late antiquity, Christians integrated themselves surprisingly smoothly into the Roman army. The bible reports the earliest Christian military service. Since state and earthly order must be provisionally accepted, even soldiers were allowed in Christian religious communities (cf. Mk 5 par; Mt 8 par; Lk 3; Acts 10). They were probably able to avoid participation in pagan rituals except in phases of persecution of Christians directed by the regional or central governments of the Roman Empire. ${ }^{10}$

With Constantine's victory at the Milvian Bridge, the Christian God was engaged for the first time to aid in battle. The reasoning behind this event was from the pagan cult-theory of "the stronger god." Clerics were not present at the battle

9 Cf. Weissenberg, Friedenslehre, 176-177.

10 Cf. Brennecke, Hanns Christoph, "Kriegsdienst und Soldatenberuf für Christen und die Rolle des römischen Heeres für die Mission”, in: Holzem, Andreas (ed.): Krieg und Christentum: Religiöse Gewalttheorien in der Kriegserfahrung des Westens (Krieg in der Geschichte, Vol. 50), Paderborn et al. 2009, 180-211. 
according to the report by Eusebius of Caesarea. ${ }^{11}$ They came into play only later in order to enable interpretation of this war in the classical scheme of divine aid. Thus a far-reaching model appeared: To prevent archaic violence in human communities ripe with conflict, a Christian variant of the "legitimation to kill as a specific correlate of power" ${ }^{\prime 2}$ was thought to be necessary. After $312 \mathrm{CE}$, Constantine went beyond placing the Christian monogram he had seen in the vision at the Milvian Bridge on the shields of his warriors, on his military standard (labarum), and on his helmet. Towards the end of his reign, Christian priests were present in imperial armies. The first weapon blessings with this XR-symbol were added, and camps included prayer tents, bishops, and military chaplains. The religious needs of the Roman army transferred from paganism to an oath of allegiance to the trinity, Christian laws, prayers, crosses, icons, and liturgies stepped into the army as well as a Christianized imperial cult, all without much modification of the pagan concepts of understanding the role of religion in wartimes. Indirectly, emperors continued the Roman tradition established in the Republican Period: Decisions about war outcomes were laid into the hands of the gods. In pre-Christian periods, bellum iustum (just war) depended especially on influencing the Gods with a ritually correct cult. This ancient theory of bellum iustum had nothing to do with ethical categories of justice. Christian clerics adopted this concept, amalgamating it with the completely different approach of the patristic theologians: So they did what pagan priests had done for the army before them to emphasize the army's dependence on divine powers. Additionally, Christianity's rich reservoir of rituals could also deliver imperial style in war. ${ }^{13}$

In order to gain a balanced perspective of early Christian developments, the religious-political contrast between the theologian's restrictive war ethic and a parallel, seemingly unproblematic transfer of pre-Christian military cults should be noted. The Christianization of army and war since late antiquity provided clerics with two positions representing two sets of demands that were difficult to reconcile and that had systems of rules based on differing responsible parties: on the one side were theologians and biblical hermeneutics and on the other side were prayers of invocation and "sacrifice". Christianity was therefore always as free as it was forced to consider its options between these poles and to provide political advice based on such considerations. Its representatives also had to both adhere to and want to provide such spiritual weapons which had descended from

11 Cf. Eusebius of Caesarea: Vita Constantini 1,29; in: De Vita Constantini, ed. Bruno Bleckmann / Horst Schneider (Fontes Christiani 83), Turnhout 2007, 184-197.

12 Stietencron, Töten, 34-35.

13 Meier, Mischa: "Der christliche Kaiser zieht (nicht) in den Krieg: 'Religionskriege' in der Spätantike?”, in: Holzem, Andreas (ed.): Krieg und Christentum: Religiöse Gewalttheorien in der Kriegserfahrung des Westens (Krieg in der Geschichte, Vol. 50), Paderborn et al. 2009, 254-278; 260. 
political religions of the ancient Orient and the pre-Christian Mediterranean. This in turn created a multitude of ambiguities and ethical problems.

\section{The Middle Ages}

In the Middle Ages, the Christian justification for war based on Augustine's peace theory - given the unsurpassed authority of this church father - held ground substantially, but was adjusted to the new realities of war: Neither the Carolingians nor the Ottonians declared to wage "holy" missionary wars to violently expand Christianity among Saxons and Slavs. The prevailing connection between war and mission was based on a pattern of justification that interpreted political unpredictability and barbarian savagery as pagan religious trademarks. The Christianization could thus appear as a means for political civilizing. ${ }^{14}$

During the High Middle Ages, especially the Treuga Dei (Peace and Truce of God) was no blessing upon war actions, but a campaign to pacify western Christianity ad extra (against the expansion of Islam) and ad intra (against the permanent aristocratic feuds destroying lands and churches). Of course, all these wars were based on the idea that taking up the Christian faith was essential for the consolidation of a violence-free space and that Christian rulers and Church representatives had the task of protection and jurisdiction in carrying out this idea. Therefore, the theory emerged that war could be engaged in by order of the Church and with the Church's authority. This sort of war should be salutary for participants, under the precondition of the warrior's right intention: to reinstate peace, to protect the church, to avoid unjust iniquities and eliminate any avarice and hate out of his heart. This was pure Augustinism. Due to the emperor - and every ruler in general - being appointed to protect not only secular order, but also the Church and the true faith, the substantially defensive basis of ethical reflections on war in Christian theology could be converted into an offensive strategy in these contexts. Securing the Treuga Dei, the fight for Church reform, the crusades against the harassment of Christian pilgrims in the Muslim world, as well as the support of heretics, gained curative qualities for the salvation of the Christian knighthood, in terms of a theology of repentance and redemption. Nevertheless, the sources for the crusades use the term bellum sacrum/sanctum as little as the collections of canonic law and moral theology through to Thomas Aquinas. Furthermore, the crusades were justified as a war for the "defense of Christianity against the threat of Muslim powers and in order to regain formerly

14 Körntgen, Ludger: "Heidenkrieg und Bistumsgründung: Glaubensverbreitung als Herrscheraufgabe bei Karolingern und Ottonen”, in: Holzem, Andreas (ed.): Krieg und Christentum: Religiöse Gewaltheorien in der Kriegserfahrung des Westens (Krieg in der Geschichte, Vol. 50), Paderborn et al. 2009, 281-304; 281. 
Christian areas". ${ }^{15}$ In this sense, the indulgence promulgated by pope Urban II as a part of the crusades propaganda was not a collective romanticization of war waging knights as martyrs - although the crusaders mostly saw themselves as such - but the indulgencies were understood as individual commutations of penance. The beneficial value of participation should be preconditioned as long as the campaign succeeded as "solely devotional (pro sola devotione)."

On the other hand, participants in crusades created their own religious logic, which was difficult to reconcile with reflections from Augustine through Gratian to Thomas Aquinas. Among crusaders and then among people including the pope who celebrated their victory in 1099 a belief in the pollutio (pollution) of holy sites by the Muslim conquerors was at work, for which an atoning purification was achieved through the bloodshed of the supposed offenders: The massacre of the inhabitants of Jerusalem in 1099 was sanctified as the violent wrath of God himself. The crusaders believed that the holy sites had to be expurgated from the stain of Muslim cultic practices. Texts of the Hebrew bible - as those analyzed above - that were originally applied to themes of blaming Israel, infidelity against the covenant and divine fate were now considered analogous paradigms of violence in the name of God. Between theological questions of justice and cultic blood vengeance, a kind of "negative compromise" had emerged. ${ }^{16}$

In wars taking place in the West against alleged enemies of the true faith, particularly in the Albigensian War against heretics in Southern France, these theories gained their own history of reception. The Christian faith, according to the indisputable consensus, could not be violently propagated and had to be accepted freely. But as is often commonplace, to circumvent this basic theological assumption people, once baptized and Christianized, could sometimes even be forced (corporaliter compellere) to comply to the assumed faith and stick to its ethical obligations and liturgical practices. Here Augustine's position towards the Donatist Schism provided authority even in wars against heretics. The Albigensian crusade was completely ineffective in the search for Cathar perfecti (apostles) and credenti (supporters) or in coping with the widespread religious syncretism. Instead, the war was preceded by another declared goal: Allegedly illegitimate rulers who did not fight the heresy were to be replaced with principes catholici (princes loyal to the Catholic Church). The condemnation of enemies of the faith as peace breakers and the kings' responsibility to protect the church to

15 Hehl, Ernst Dieter: "Heiliger Krieg - Eine Schimäre? Überlegungen zur Kanonistik und Politik des 12. und 13. Jahrhunderts", in: Holzem, Andreas (ed.): Krieg und Christentum: Religiöse Gewalttheorien in der Kriegserfahrung des Westens (Krieg in der Geschichte, Vol. 50), Paderborn et al. 2009, 323-340; 325.

16 Angenendt, Arnold: “Die Kreuzzüge: Aufruf zum 'gerechten' oder zum 'heiligen' Krieg?”, in: Holzem, Andreas (ed.): Krieg und Christentum: Religiöse Gewalttheorien in der Kriegserfahrung des Westens (Krieg in der Geschichte, Vol. 50), Paderborn et al. 2009, 341-367, 361 . 
evade God's wrath derived essentially from the concept of a Christian empire in late antiquity and of a faithful kingship in the Carolingian and Ottonian periods; the Treuga Dei was intended to bind the local noblemen in honor and assigned the leadership for the whole process to the church authorities: the pope and his legates. Hence, the spectrum of just reasons for war was - according to the situation in south-west France during the $12^{\text {th }}$ and $13^{\text {th }}$ centuries - expanded again to include "the replacement of local and territorial rulers who condoned hereticism with Catholic aristocrats." ${ }^{17}$ Nonetheless, from a legal and theological perspective, this was not an escalation to a sanctified 'divine war', it was a well expected opportunity to integrate the hitherto independent south into the realm of the French kingdom. Being declared as a campaign to defend the church, it was covered with papal indulgencies as the crusades to Jerusalem or the Reconquista in Spain.

The history of medieval war theory accounts argumentatively for a process of a permanent re-interpretation of 'just war'-ideas; 'holy war' was not at all a central term in these debates, it would occur later and under different preconditions. In fact, the specifically religious reasons for 'just war' steadily expanded up to the severe and heated debates in $15^{\text {th }}$ and $16^{\text {th }}$ centuries Spain on the inhuman colonization and Christianization of the so called 'New Indies' in Latin America. Erasmus of Rotterdam was the first to criticize war as destruction of the divine order of creation and damage to state, society, and economy in his early humanist text Dulce bellum inepertis ${ }^{18}$, but in the face of confessional conflict erupting in Imperial Germany and the Turkish threat in the Southeast, even Erasmus considered it necessary to relativize the ethical primacy of a total Christian pacifism.

\section{The Early Modern Period}

The confessional conflicts that dominated the early modern period constituted a multi-layered challenge for the Christian formation of war theory. Even more than the Middle Ages, the confessional wars of Europe's early modern period were assessed to be the parade ground for bloodthirsty fanaticized religion, since the European enlightenment movements began to criticize confessional orthodoxies of all sorts. The discreteness of the political sphere, the emancipation from

17 Oberste, Jörg: "Krieg gegen Ketzer? Die defensores, receptatores und fautores von Ketzern und die principes catholici in der kirchlichen Rechtfertigung des Albigenserkriegs", in: Holzem, Andreas (ed.): Krieg und Christentum: Religiöse Gewalttheorien in der Kriegserfahrung des Westens (Krieg in der Geschichte, Vol. 50), Paderborn et al. 2009, 368-391; 386.

18 Cf. Erasmus von Rotterdam: "Dulce bellum inexpertis", in: Adagia (Nr. 3001). Opera omnia Desiderii Erasmi Roterodami. Recognita et adnotatione critica instructa notisque illustratae, Bd. 2,7, Amsterdam / Heidelberg 1999, 11-44. 
religious authorities and the claim to control and domesticate fanaticism and extremism; all of these elements considered typical for modern Western selfunderstanding can be considered as consequences drawn from war experiences during the era of confessionalism.

Christian theory development, which was authoritative for political decisions, interpretive models and war experiences of protagonists in the $16^{\text {th }}$ and $17^{\text {th }}$ centuries, was once again in no way a unilineal process matching these subsequent apodictic judgments. Martin Luther's Two Kingdoms resp. Two Governments Doctrine, a part of which is applicable for military interpretation, was a first attempt to subtly differentiate areas of worldly law and agency from areas within which God related to human beings. This doctrine must be understood as an enhancement from medieval political theory and not as a reversal thereof. In one decisive respect a boundary is set for any secular authority: It has no authorization to intervene in the interpretation of the Gospel, although Luther had to concede that the shaping of new protestant church orders could not be established without extensive influence of the civil authorities. In another respect, Luther assessed the (hitherto papal and episcopal) influence as an abuse of clerical power in the political order of the German princes' realms. Thus he opened a political playing field, wherein proclamations of ecclesiastical power were no longer legitimate. The terrena civitas, Luther was convinced, is not to be ruled by the Gospel: Here the secular authority has autonomous penal power to repel the devil's efforts to destroy the societal order of Christianity.

As important as the Two Kingdoms Doctrine was for any theory of the state in early modernity, it also had a blind side. In the case of the German Peasants' War, war theory in the Lutheran formulation lost its affiliation to practical moral philosophy and moral theology, which it had held since late antiquity and throughout the whole of the Middle Ages, and which it would maintain in Catholic Baroque Scholasticism in the early modern period. The political autonomy of secular authorities could hardly be countered, since for Luther "the deciding theme was not the form of authority, but the necessity for control of human evil". ${ }^{19}$ The Two Kingdom Doctrine thus supported, but did not control, the military aspect of nation building.

The debate developed differently in the reformed nations of Switzerland and England. The Reformation in Zurich and Geneva wanted to shape the world using the norms of the Gospel. "What differentiates the Zwinglian and Calvinist Churches [is] the claim that the Kingdom of Christ is etiam externum" ${ }^{20}$ In ac-

19 Leppin, Volker: "Das Gewaltmonopol der Obrigkeit: Luthers sogenannte ZweiReiche-Lehre und der Kampf zwischen Gott und Teufel”, in: Holzem, Andreas (ed.): Krieg und Christentum: Religiöse Gewalttheorien in der Kriegserfahrung des Westens (Krieg in der Geschichte, Vol. 50), Paderborn et al. 2009, 403-414; 411.

20 Schmidt, Heinrich Richard: "Religion und Krieg im Reformiertentum", in: Holzem, Andreas (ed.): Krieg und Christentum: Religiöse Gewalttheorien in der Kriegs- 
cordance with the covenant theology from the Old Testament, authority had to actively secure the true faith and help expand the Kingdom of Christ on earth. The justification for this lay not in the conventional responsibility of Church protection as debated in the Middle Ages, but in the reception of deuteronomistic historical theology: A ruler and their people who injure the conditions of the covenant will be punished by God in heaven with defeat in war, exile and banishment from world history. In this context, the concept of "holy war" appeared for the first time in reformed war theology. It justified a truly Christian people's right to disobedience and civil war against tyrannical rulers. The persecution of the reformed faith - for example in the Habsburg Netherlands or in France - was interpreted as the most specific form of unjustified violence.

On the other hand, in "patriarchal German principalities integrated in the state order of the Holy Roman Empire"21, the phenomenon of dissimulation of religious war and religious justification for violence was prevalent in both large confessions. The wars that had occurred in the Empire because of differences of faith were explained by the emperor as the execution of the order of 'Landfrieden' (public peace), broken by the protestant princes, and vice versa by those princes as legal defense of their constitutionally guaranteed freedom against imperial absolutism in questions of conscience. To take the long view, the dissimulation of religious war proved to be a motor of juridification (Verrechtlichung) of politics and military independently of questions of religious truth. An essential consequence of German peace and constitutional orders after 1648 was the exclusion of religion from the concept of just war. The conflict between increasing multinationalism in the European system of power and the old universal concepts of Christianitas (Christianity), Imperium (Empire), or Monarchia universalis (universal monarchy) played as much of a role as the internal establishment of states that were undertaken as an emancipatory dissolution of greater, cross-national alliances. In this process, the state tried to take control over religion, while the bearers of religion continued to argue the supremacy of religious arguments for rulers' political decision-making.

It was decisive for the development of the relationship between Christianity and war in the early modern period that the observation that theoretical organization and moral evaluations of war did not break down only along confessional lines, but also according to the place of debate in society. After the peace treaty of Augsburg 1555, the Emperors and the Imperial princes no longer mobilized the medieval right of defeating heresy as a war theory. But this differed from the

erfahrung des Westens (Krieg in der Geschichte, Vol. 50), Paderborn et al. 2009, 415-438; 415 .

21 Brendle, Franz: "Der Religionskrieg und seine Dissimulation. Die 'Verteidigung des wahren Glaubens' im Reich des konfessionellen Zeitalters”, in: Holzem, Andreas (ed.): Krieg und Christentum: Religiöse Gewalttheorien in der Kriegserfahrung des Westens (Krieg in der Geschichte, Vol. 50), Paderborn et al. 2009, 457-469; 457. 
assessments made in many academic faculties of theology on both sides, in the religious orders, and in the majority of public opinion that developed powerfully after the Reformation: Here, the religious war was a reality up until 1648, expected and feared, publicly fought and suffered. ${ }^{22}$ The juridification and nationalization of war disregarded this during the early modern period, drawing instead on post-confessional theories of state, on debates of natural rights, and on the Enlightenment.

\section{A Sketch of Christian War Theories in the Wake of Modern War Ideologies}

During the Cabinet Wars of the $18^{\text {th }}$ century, the military was increasingly nationalized. In the process, rulers' authority for interpreting and organizing also the religious aspects of war grew steadily. Any religious service in the armies underwent strict control by military regimes and their focused aim: motivating men to fight and die.

On the other hand, after 1789 this nationalization of war was overrun with radicalizing forms of political awareness: concepts and myths about "the people" and "the nation". These new ideologies had the greatest influence during the wars triggered by the French revolution and its combatants, and afterwards the Napoleonic wars. The nation in itself was esteemed as a secularized 'holiness'; patriotism provoked new forms of quasi-religious enthusiasm. Those motives of Christian war ethics that fenced off and limited war were as lost as its secular remainders in public international law, established after 1648. Instead, a process of anti-secularization set in, encouraging the peoples and nations to establish an overwhelming political transcendence for which new forms of cult were created. For the relationship between war and Christianity in European modernity, these political-ideological sacralizations of peoples, nations and sometimes the revolution itself brought about ambivalent consequences. Starting with the revolutionary wars, but throughout the whole of the $19^{\text {th }}$ and $20^{\text {th }}$ centuries, Christianity was forced to confront and meanwhile integrate this new sacralization of politics. War gained something 'holy' precisely in this context of a quasi-religious, political transcendence. ${ }^{23}$ Everywhere, modern Christianity had to comment on political

22 Cf. Holzem, Andreas: "Gott und Gewalt. Kriegslehren des Christentums und die Typologie des 'Religionskrieges'”, in: Beyrau, Dietrich / Hochgeschwender, Michael / Langewiesche, Dieter (eds.), Formen des Krieges. Von der Antike bis zur Gegenwart (Krieg in der Geschichte, Bd. 37), Paderborn et al. 2007, 371-413.

23 Graf, Friedrich Wilhelm: "Sakralisierung von Kriegen: Begriffs- und problemgeschichtliche Erwägungen”, in: Schreiner, Klaus (ed.): Heilige Kriege. Religiöse Begründungen militärischer Gewaltanwendung: Judentum, Christentum und Islam im 
religiosity as it grew more and more dominant as a source of meaning. Bishops and theologians could not avoid supporting this evolution of enthusiastic ideologies with Christian explanations. Meanwhile, they adhered to alternative traditions that interpreted war as a calamity of God's punishment, as a call to penance for individual and collective sins and as a catharsis of modern, post-revolutionary societies to purify their liberal, disbelieving culture. The Churches regarded modern war as a missionary field, because war stirred the routines of irreligious lifestyles up and irritated religious neglect with the threat of an untimely death of masses. In short: War offered an opportunity to speak about collective responsibility and individual con- or reversion. The individual "sacrifice" of every soldier's life was considered part of atonement for a collective sin, identified with the spiritual shortcomings of modern society. The leading voice did not critically question war, but spoke of readiness to make oblations.

In the greater European and American denominations, none of these conventional war theories as they were applied to the situation of modern mass wars survived May 8, 1945. Certainly, the consequences of this long debate about war and Christianity should not be overlooked: Christian war ethics required justification for both ius ad bellum and ius in bello and condemned excessive violence both generally and in individual cases. Christianity has held fast to the basic idea that war is not an elevated form of existence, but one of the most horrific consequences of sin. Conversely, it may hardly be claimed that the increasing secularization of the political world has considerably fostered peace. The secular law of nations rests, rather, in its essential basis on the fruits of Christian thought about war ethics.

Only after the Second World War, under the banner of the Cold War, the atomic arms race and the international proxy wars in Korea, Vietnam, and Africa, a broad debate began in Europe and North America about the prospects of peace in international political institutions and processes. Parallel to this, the first serious and numerically important Christian peace movements were established. Since then, the question of Christian war theory has been posed completely differently; these debates take leave of the old concepts, mentalities and rituals. Instead, they emphasize an alternative idea of God's partiality: God can no longer be imagined as partial to this or that warring party who claim 'just' reasons for their own campaign. Recently challenged anew by the problem of military crisis interventions in collapsing states, in genocides and against Islamist terror groups, Christianity in the $21^{\text {st }}$ century has had to reflect the basic idea that God cannot remain neutral in the face of mass killings and hardship deaths. The vast majority of Christians today formulate God's partiality differently; they postulate God's engagement as for humane life for all people, following the focus of contemporary Bible reception. Out of this, the fundamental question arises of how such a

Vergleich (Schriften des Historischen Kollegs. Kolloquien, Bd. 78), München 2008, 1-30; 7. 
theologically basic option may be formulated and transferred into political processes so that the Augustine pacificus esse (peaceful existence) of Christianity may gain new credibility.

\section{References}

Angenendt, Arnold: “Die Kreuzzüge: Aufruf zum 'gerechten' oder zum 'heiligen' Krieg?”, in: Holzem, Andreas (ed.): Krieg und Christentum: Religiöse Gewaltheorien in der Kriegserfahrung des Westens (Krieg in der Geschichte, Vol. 50), Paderborn et al. 2009, 341-367.

Beyrau, Dietrich / Hochgeschwender, Michael / Langewiesche, Dieter (eds.): Formen des Krieges: Von der Antike bis zur Gegenwart (Krieg in der Geschichte, Bd. 37), Paderborn et al. 2007.

Brendle, Franz: "Der Religionskrieg und seine Dissimulation. Die 'Verteidigung des wahren Glaubens' im Reich des konfessionellen Zeitalters", in: Holzem, Andreas (ed.): Krieg und Christentum: Religiöse Gewalttheorien in der Kriegserfahrung des Westens (Krieg in der Geschichte, Vol. 50), Paderborn et al. 2009, 457-469.

Brennecke, Hanns Christoph, "Kriegsdienst und Soldatenberuf für Christen und die Rolle des römischen Heeres für die Mission", in: Holzem, Andreas (ed.): Krieg und Christentum: Religiöse Gewaltheorien in der Kriegserfahrung des Westens (Krieg in der Geschichte, Vol. 50), Paderborn et al. 2009, 180-211.

Erasmus von Rotterdam: "Dulce bellum inexpertis", in: Adagia (Nr. 3001). Opera omnia Desiderii Erasmi Roterodami. Recognita et adnotatione critica instructa notisque illustratae, Bd. 2,7, Amsterdam / Heidelberg 1999, 11-44.

Erler, Michael, "Ursachenanalyse von Krieg und Frieden bei Platon und in der hellenistischen Philosophie", in: Holzem, Andreas (ed.): Krieg und Christentum: Religiöse Gewalttheorien in der Kriegserfahrung des Westens (Krieg in der Geschichte, Vol. 50), Paderborn et al. 2009, 169-179.

Eusebius of Caesarea: Vita Constantini 1,29; in: De Vita Constantini, ed. Bruno Bleckmann / Horst Schneider (Fontes Christiani 83), Turnhout 2007, 184-197.

Graf, Friedrich Wilhelm: "Sakralisierung von Kriegen: Begriffs- und problemgeschichtliche Erwägungen”, in: Schreiner, Klaus (ed.): Heilige Kriege. Religiöse Begründungen militärischer Gewaltanwendung: Judentum, Christentum und Islam im Vergleich (Schriften des Historischen Kollegs. Kolloquien, Bd. 78), München 2008, 130.

Groß, Walter, “Keine 'Heiligen Kriege' in Israel. Zur Rolle JHWH's in Kriegsdarstellungen der Bücher Jos bis 2Kön”, in: Holzem, Andreas (ed.): Krieg und Christentum: Religiöse Gewaltheorien in der Kriegserfahrung des Westens (Krieg in der Geschichte, Vol. 50), Paderborn et al. 2009, 107-127.

Hehl, Ernst Dieter: "Heiliger Krieg - Eine Schimäre? Überlegungen zur Kanonistik und Politik des 12. und 13. Jahrhunderts", in: Holzem, Andreas (ed.): Krieg und Christentum: Religiöse Gewaltheorien in der Kriegserfahrung des Westens (Krieg in der Geschichte, Vol. 50), Paderborn et al. 2009, 323-340. 
Holzem, Andreas (ed.): Krieg und Christentum. Religiöse Gewalttheorien in der Kriegserfahrung des Westens (Krieg in der Geschichte, Vol. 50), Paderborn et al. 2009.

Holzem, Andreas: "Geistliche im Krieg und die Normen des Kriegsverstehens: Ein religionsgeschichtliches Modell zu Ritual, Ethik und Trost zwischen militärischer Kulttradition und christlicher Friedenspflicht”, in: Brendle, Franz / Schindling, Anton (eds.): Geistliche im Krieg, Münster 2009, 41-85.

Holzem, Andreas: "Gott und Gewalt. Kriegslehren des Christentums und die Typologie des 'Religionskrieges'”, in: Beyrau, Dietrich / Hochgeschwender, Michael / Langewiesche, Dieter (eds.), Formen des Krieges. Von der Antike bis zur Gegenwart (Krieg in der Geschichte, Bd. 37), Paderborn et al. 2007, 371-413.

Körntgen, Ludger: "Heidenkrieg und Bistumsgründung: Glaubensverbreitung als Herrscheraufgabe bei Karolingern und Ottonen", in: Holzem, Andreas (ed.): Krieg und Christentum: Religiöse Gewalttheorien in der Kriegserfahrung des Westens (Krieg in der Geschichte, Vol. 50), Paderborn et al. 2009, 281-304.

Leppin, Volker: "Das Gewaltmonopol der Obrigkeit: Luthers sogenannte Zwei-ReicheLehre und der Kampf zwischen Gott und Teufel", in: Holzem, Andreas (ed.): Krieg und Christentum: Religiöse Gewalttheorien in der Kriegserfahrung des Westens (Krieg in der Geschichte, Vol. 50), Paderborn et al. 2009, 403-414.

Luz, Ulrich: "Feindesliebe und Gewaltverzicht: Zur Struktur und Problematik neutestamentlicher Friedensideen", in: Holzem, Andreas (ed.): Krieg und Christentum: Religiöse Gewalttheorien in der Kriegserfahrung des Westens (Krieg in der Geschichte, Vol. 50), Paderborn et al. 2009, 137-149.

Meier, Mischa: "Der christliche Kaiser zieht (nicht) in den Krieg: 'Religionskriege' in der Spätantike?", in: Holzem, Andreas (ed.): Krieg und Christentum: Religiöse Gewaltheorien in der Kriegserfahrung des Westens (Krieg in der Geschichte, Vol. 50), Paderborn et al. 2009, 254-278.

Nicklas, Tobias: "Der Krieg und die Apokalypse: Gedanken zu Offb 19,11-21", in: Holzem, Andreas (ed.): Krieg und Christentum: Religiöse Gewaltheorien in der Kriegserfahrung des Westens (Krieg in der Geschichte, Vol. 50), Paderborn et al. 2009, $150-165$.

Oberste, Jörg: "Krieg gegen Ketzer? Die defensores, receptatores und fautores von Ketzern und die principes catholici in der kirchlichen Rechtfertigung des Albigenserkriegs", in: Holzem, Andreas (ed.): Krieg und Christentum: Religiöse Gewalttheorien in der Kriegserfahrung des Westens (Krieg in der Geschichte, Vol. 50), Paderborn et al. 2009, 368-391.

Schmidt, Heinrich Richard: "Religion und Krieg im Reformiertentum", in: Holzem, Andreas (ed.): Krieg und Christentum: Religiöse Gewaltheorien in der Kriegserfahrung des Westens (Krieg in der Geschichte, Vol. 50), Paderborn et al. 2009, 415438.

Stietencron, Heinrich von: “Töten im Krieg: Grundlagen und Entwicklungen”, in: Ders. (ed.): Töten im Krieg, Freiburg et al. 1995, 17-53.

Weissenberg, Timo J.: Die Friedenslehre des Augustinus: Theologische Grundlagen und ethische Entfaltung, Stuttgart 2005. 
Andreas Holzem, Faculty of Catholic Theology, Eberhard-Karls-Universität Tübingen, Church History in the Middle and Modern Ages, Liebermeisterstr. 12, 72076 Tübingen, Germany, e-mail: andreas.holzem@uni-tuebingen.de

Citation: Holzem, Andreas: "Theological War Theories", in: Kallhoff, Angela / SchulteUmberg, Thomas (eds.): Moralities of Warfare and Religion (J-RaT 2018 / 1) pp. 21-37.

Datum der Publikation: 16.07.2018 